Ogea Pozo, M. (2020). Subtitling documentaries: A earning tool for enhancing scientific translation skills. Current Trends in Translation Teaching and Learning E, 7, 445478.

\title{
SUBTITLING \\ DOCUMENTARIES: A \\ LEARNING TOOL FOR \\ ENHANCING SCIENTIFIC \\ TRANSLATION SKILLS
}

María del Mar Ogea Pozo

University of Córdoba

\section{Abstract}

This paper examines the use of subtitles as a learning tool for developing skills required for scientific translation, in the framework of the course "Scientific and Technical Translation" included in the Translation and Interpreting Studies degree at the University of Cordoba. For that purpose, in the present study we aim to discuss and describe the benefits provided by this modality of audiovisual translation by presenting an overview of the previous studies focused on the effectiveness of subtitling in foreign language (FL) learning. However, we intend to go deeper and propose the integration of subtitling not only in translation studies curriculum, but 
Ogea Pozo, M. (2020). Subtitling documentaries: A earning tool for enhancing scientific translation skills. Current Trends in Translation Teaching and Learning E, 7, 445478.

more specifically, in a scientific translation course. Furthermore, the documentary genre is postulated as an optimal audiovisual media to be used for FL specialised language learning. The subtitling activity consisted of three stages: viewing of an informational documentary short movie with original English subtitles, documentation, and translation into Spanish. In order to confirm whether this subtitling practice raises students' motivation and, as a result, brings positive learning results, this study is based on the responses obtained in a questionnaire completed by the participants in the experiment. The main questions are related to the role of multiple semiotic systems as a support for textual comprehension and learning, and the acquisition of specialised terminology, as well as the students' motivation towards a simulation of a professional translation assignment.

Keywords: Audiovisual translation, Scientific translation, Documentary genre, Subtitling, FL language

\section{INTRODUCTION}

Since the Common European Framework of Reference for Languages acknowledged the usefulness of subtitled audiovisual material as a basic tool for instrumental FL learning, many studies have demonstrated its effectiveness, including the recent works published by King (2002), Mayer (2009), Neves (2004), Talaván (2011, 2012), Sokoli, Zabalbeascoa and Fountana (2011), Díaz-Cintas (2012), Incalcaterra and Lertola 
Ogea Pozo, M. (2020). Subtitling documentaries: A earning tool for enhancing scientific translation skills. Current Trends in Translation Teaching and Learning E, 7, 445478.

(2014), and Soler (2017). Subtitling seems to have earned greater attention not only in the research field but, consequently, in the teaching and learning framework at primary, secondary and university levels. Students feel comfortable when working in a multimedia environment, and they are increasingly familiarised with this modality of audiovisual translation beyond the educational context (as they are consumers of subtitled audiovisual productions). Therefore, they find the practice of subtitling easy and attractive, even when learning any other interdisciplinary subject related to Translation Studies.

This interdiciplinary approach in Translation Studies lead us to believe that documentaries could be an adequate educational material based on subtitling scientific audiovisual texts. We must point out that the documentary genre has gained a significant popularity among your audience due to the latest documentary films and series available in VOD platforms, so this type of activity could be welcomed in the classroom and valued as a dynamic tool to enhance skills for scientific translation.

However, if we deviate from the aspects exclusively related to FL teaching in the broadest sense, the literature available on the documentary genre itself 
Ogea Pozo, M. (2020). Subtitling documentaries: A earning tool for enhancing scientific translation skills. Current Trends in Translation Teaching and Learning E, 7, 445478.

seems to be reduced to a scarce number of publications, although the works found have been extremely useful for this research work. Documentaries have been subject to a few studies focused on their narrative structures, design and production within the current television panorama, like the papers published by León $(2001,2002)$ and Paricio (2002), as well as those studies focused on their main characteristics - regarding specific aspects of translation-carried out by Matamala (2009), García (2010), and Ogea (2018).

This paper aims to prove the usefulness of subtitling as an optimal tool for teaching specialised language in the framework of the course "Scientific and Technical Translation." It should be noted that we will be using the nomenclature "subtitling" to refer to interlinguistic subtitles, namely, those subtitles that necessarily involve the switch from a source language to a target language.

So as to validate this hypothesis, we will first delve into theoretical aspects related to the documentary genre and the translation of scientific documentaries, with the purpose of outlining the benefits this type of audiovisual translation has to offer to learners pursuing a degree in Translation and Interpreting Studies. In order to confirm 
Ogea Pozo, M. (2020). Subtitling documentaries: A earning tool for enhancing scientific translation skills. Current Trends in Translation Teaching and Learning E, 7, 445478.

whether AVT may render positive learning results, we will attempt to examine and verify the advantages provided by the practice of subtitling in the classroom by means of the translation of a scientific documentary. In this respect, we will be pursuing our main objective: to put forth the practice of subtitling informational programmes as a tool for the acquisition of different skills required for scientific translation. For that purpose, a short informational documentary film will be translated and subtitled into Spanish, and several activities grouped in three stages will be completed during the whole process. The evaluation of the entire activity will be based on two different criteria: 1) a questionnaire filled in by students, where participants can assess the activity in terms of FL learning, motivation, and usefulness of the semiotic codes for the acquisition of vocabulary and textual comprehension, and b) the learning outcomes evinced by the students' marks achieved in the final evaluation.

\section{SUBTITLING AS A LEARNING TOOL}

The use of audiovisual material in FL learning can be justified by several studies that set the theoretical basis for this didactic approach. We must first adhere to the Cognitive Theory of Multimedia 
Ogea Pozo, M. (2020). Subtitling documentaries: A earning tool for enhancing scientific translation skills. Current Trends in Translation Teaching and Learning E, 7, 445478.

Learning by Mayer (2009), which establishes that people have a limited cognitive capacity and they learn from verbal and visual information-processing channels. Therefore, when words and pictures are presented together on screen, the learner's cognitive capacity increases thanks to the dual-channel capabilities of humans (Mayer, 2009). Additionally, the use of subtitles as a FL learning tool has been supported by Gottlieb (2004), who proposes subtitles in foreign productions as an important and effective reading drill for both adults and children, as well as an optimal tool for improving foreignlanguage vocabulary skills.

On the other hand, Incalcaterra and Lertola (2014) highlight the positive effect of this modality of audiovisual translation and consider subtitling as "a receptive and mediating activity that can become an integral part of the foreign language curriculum" ( $p$. 74), which may work as an "invaluable tool" that can benefit students on various levels during the foreign language learning process. The authors agree with Gottlieb's theory, observing that students in nowadays society are accustomed to deal with polysemiotic multimedial texts. Hence, this familiarity with audiovisual media seems to be the key to ensure a good reception of subtitling activities in educational contexts. Incalcaterra and 
Ogea Pozo, M. (2020). Subtitling documentaries: A earning tool for enhancing scientific translation skills. Current Trends in Translation Teaching and Learning E, 7, 445478.

Lertola (2014) assert that this learning method may be more effective than the four-skill model (reading, listening, speaking, writing) which is too restrictive when compared to multifaceted and multi-skills AV learning tools that foster listening and reading comprehension, as well as vocabulary acquisition.

Soler (2017) points out that, since the beginning of the 21st century, audiovisual translation has been taking its rightful place in language teaching, as it has been proven to be an ideal component for FL learning. More specifically, she takes subtitling as a pedagogical tool for the acquisition of vocabulary in a foreign language and employs activities that consist of either watching subtitles or filling in the gaps in the subtitles text. Moreover, she explains that this modality is especially fruitful in the learning process, since students do not work with isolated words, but instead those words are "part of a larger unit" (Soler, 2017, p. 183): the audiovisual text. Therefore, words gain a deeper meaning in a more productive learning.

Alternatively, Sokoli et al. (2011) suggest the idea of asking language learners to add or modify subtitles by themselves on a subtitling simulator, rather than undertaking several activities that consist of watching subtitled videos. The authors explain 
Ogea Pozo, M. (2020). Subtitling documentaries: A earning tool for enhancing scientific translation skills. Current Trends in Translation Teaching and Learning E, 7, 445478.

that this practice "implies involving the learners in a simulated real-world task whose outcome, unlike watching subtitles or using viewing techniques, is a tangible, shareable product" (p. 220), that is to say, the subtitled video.

To conclude this section, it is worth referring to Talaván (2012), who remarks that, in order to be truly effective for the FL teaching-learning, subtitles must be used with a clear purpose, which goes beyond a mere viewing on the screen. Our specific objective was not to teach a second language in FL in a broad sense, but to target specialized terminology and textual standards proper to scientific language in English and Spanish. This main objective was a decisive factor in designing the phases of the project to be performed in the classroom.

\subsection{Subtitling in the Scientific Translation classroom}

At this point, there seems to be no doubt that subtitles are a valid, creative, and productive learning tool that is well received by teachers and students. Particularly, in this study we will ponder them as an effective method for future translators' training, in the context of scientific translation. 
Ogea Pozo, M. (2020). Subtitling documentaries: A earning tool for enhancing scientific translation skills. Current Trends in Translation Teaching and Learning E, 7, 445478.

Thus, in this section we will look into the benefits of subtitling scientific documentaries within the lectures of "Scientific Translation." Therefore, we will limit ourselves to outline those aspects that we consider to be most beneficial for students enrolled in the abovementioned course.

Firstly, this activity demonstrates the interdisciplinary nature of translation and enables students to acquire multiple skills required for audiovisual translation (for instance, the ability to deal with information contained in different codes of meaning, image constraints, and space and time limitations) as well as for scientific translation (terminology and textual standards for scientific texts in both languages), as well as technical aspects related to the use of software tools. As a result, subtitling scientific AV texts is a complex task but, at the same time, it becomes a fascinating challenge for students that permits them develop a great range of translation competences. So, we maintain that subtitling informational audivisual programmes can be a comprehensive and enriching practice for students.

The presence of multiple signs helps viewers to comprehend the scientific text, which might be difficult to understand at a first glance. Therefore, 
Ogea Pozo, M. (2020). Subtitling documentaries: A earning tool for enhancing scientific translation skills. Current Trends in Translation Teaching and Learning E, 7, 445478.

the use of subtitles in the classroom lets us bring out the benefits of audiovisual texts as a learning tool, as it makes students pay attention to the different codes of meaning and interpret the information contained. This multimodal interaction constructs meaning and provides dynamism to the learning process, bringing "language to life" (King, 2002, p. 510). The author explains that the use of audiovisual productions compensates for all the shortcomings in the language learning experience, so this theory that may be the base for our study, as we intend to compensate the possible lack of scientific knowledge with the presence of aditional information within multiple sign systems. King (2002) emphasizes the positive impact of using audiovisual products in the classroom, as she explains that "it is a refreshing learning experience for students who need to take a break from rote learning of endless English vocabulary and drill practices, and replace it with something realistic, a dimension that is missing in textbook-oriented teaching" (p. 510).

According to Neves (2004), the multisemiotic nature of these texts is crucial for achieving a good reception and motivation which, therefore, provides satisfactory learning results: 
Ogea Pozo, M. (2020). Subtitling documentaries: A earning tool for enhancing scientific translation skills. Current Trends in Translation Teaching and Learning E, 7, 445478.

The magical enchantment of the moving image, the attraction of working with computers and electronic equipment and, above all, the fun element, makes tiresome tasks light and makes language learning pleasurable. Experience has shown that, while learning how to subtitle, students gain a greater command of language usage, in the broadest of senses and above all, find pleasure in manipulating text to achieve the best possible results. (p. 38)

Therefore, subtitling scientific documentaries might be a positive experience, with regard to the acquisition of scientific vocabulary, the interpretation of the message and the identification of linguistic aspects (marked speech, register, sociolect, collocations, etc.)

\subsection{Science documentaries as a form of specialised translation}

In order to teach scientific translation by means of audiovisual texts, it is important to select some adequate material which complies with the appropriate degree of specialisation, as indicated in the specific competences to be acquired by students. That is the reason why we opted for the 
Ogea Pozo, M. (2020). Subtitling documentaries: A earning tool for enhancing scientific translation skills. Current Trends in Translation Teaching and Learning E, 7, 445478.

documentary genre, which is closely linked to specialised translation, as the topics and terminology are usually related to a particular field of expertise (or even more than one). When referring to specialised terminology, we must take into consideration the definition suggested by Cabré (1999, as cited in Matamala, 2009, p.113), who asserts that terms are multidimensional lexical units with a specialised value in a specific discourse, so translators must attend to all the values associated them and render the exact information in the target language. According to Matamala (2009), the first steps translators must undertake are to carry out terminological searches, as well as to extract the maximum amount of information from the audiovisual programme itself, without isolating units from their context, as images may have a descriptive role and contain essential clues when finding the equivalent in the target language.

In this respect, León (2002) perceives science and the audiovisual media as intrinsic forms of knowledge and points out that the informational documentary is a perfect genre for presenting scientific content in a synthetic way, as well as for disseminating scientific information to the general audience. In order to design the activity presented in this study, we chose an informational documentary 
Ogea Pozo, M. (2020). Subtitling documentaries: A earning tool for enhancing scientific translation skills. Current Trends in Translation Teaching and Learning E, 7, 445478.

titled "Jellyfish", available in the National Geographic website. We believe that this type of documentary is ideal for our students, as its content presents a "balance between scientific accuracy and journalistic interest"(León, 2001, p. 254), because scientific issues are communicated in an interesting and comprehensible way that may result in a positive response in the classroom. Our first objective was to draw students' attention in the activity, so we tried to approach scientific knowledge through a documentary that referred to a peculiar and strange topic: the immortality of jellyfish. According to León (2001, p. 257), this "interest factor" is particularly effective for the divulgation of science, so we thought that could get our students interested in this anomalous phenomenon.

Besides the appeal of watching and subtitling audiovisual media in the classroom, documentaries seem to be the perfect material as they entail a significant level of difficulty (Paricio, 2002). This author underlines the importance of acquiring specific knowledge prior to viewing the film, as the comprehension of the objectives, hypothesis, demonstrations and findings usually require a previous training on the field, which may be highly specialised. He also observes that science involves 
Ogea Pozo, M. (2020). Subtitling documentaries: A earning tool for enhancing scientific translation skills. Current Trends in Translation Teaching and Learning E, 7, 445478.

a form of discourse demanding conceptual accuracy and terminological precision, that means referencing to concepts, languages and representational forms that pose a moderate difficulty for the public, or even the most absolute opacity in some occasions. Paricio's theory reinforces our idea that science documentaries may be an adequate tool in the context of teaching Scientific Translation, as the content in this type of audiovisual media matches the characteristics of any scientific written text and, therefore, fulfils the expectations concerning the competencies that students should acquire in this course.

We must bear in mind that this audiovisual genre is one of the trickiest challenges for translators. Documentaries are characterized by the presence of specialised vocabulary and different registers (if a narrator and several interviewer and interviewees take part). Some other added difficulties are intrinsic to the translation of documentaries, for instance, the necessity of documentation in the field of expertise, and occassionally, in multiple fields if different topics are dealt with during the story plot (Ogea, 2018). In this sense, Matamala (2009) states that "the translation of documentaries tends to put higher demands on the translator as it requires a documentation process longer than that of a TV 
Ogea Pozo, M. (2020). Subtitling documentaries: A earning tool for enhancing scientific translation skills. Current Trends in Translation Teaching and Learning E, 7, 445478.

episode or a cartoon" (p. 110). Moreover, she observes that documentaries deal with a wide range of subjects, so this multidisciplinary nature of documentaries forces audiovisual translators to do research and undertake terminological searches in multiple and very specialised areas. For this purpose, they should consult all kinds of specialised reference works, terminological databases, internet resources, parallel corpora and, if possible, to ask specialist (Matamala, 2009). Once the monolingual research is done and the meaning of the term is fully understood, the translator will be able to search and identify the adequate equivalent that renders the same level of specificity.

On the other hand, García (2010) stresses the mixed nature of this genre, explaining that documentaries must be considered audiovisual texts because of their mode of communication, but also specialized texts for their content and topics. This fact turns documentaries into the perfect material for an interdisciplinary approach in the classroom, since students will be able to develop the necessary skills for scientific and audiovisual translation.

Given the aforementioned, we can hypothesize that the combination of subtitling and scientific documentaries in the "Scientific Translation" 
Ogea Pozo, M. (2020). Subtitling documentaries: A earning tool for enhancing scientific translation skills. Current Trends in Translation Teaching and Learning E, 7, 445478.

classroom will allow students to experience firsthand the specific difficulties of translatinf a specialized text, while they can practice subtitling during the simulation of a professional project. This activity consists of three phases designed to facilitate the acquisition of various skills, not only from a linguistic point of view but also from a pragmatic, phonological and cultural approach. We expect that this challenging and arduous task will be fruitful thanks to the student's active participation and high motivation, which should result in positive results derived from this interdisciplinary learning.

\section{THE PROJECT: SUBTITLING THE NATIONAL GEOGRAPHIC DOCUMENTARY JELLYFISH}

The main objective of the project was to use educational material for enhancing skills required for scientific translation, by means of an educational tool based on video subtitling that differs from the traditional written texts, as well as a questionnaire to assess the students' response, in terms of motivation, participation and, specially, learning results. This empirical research was conducted during the first semester of the 2018/2019 academic year, within the context of the course "Scientific and Technical Translation (English-Spanish)" taught in 
Ogea Pozo, M. (2020). Subtitling documentaries: A earning tool for enhancing scientific translation skills. Current Trends in Translation Teaching and Learning E, 7, 445478.

the Translation and Interpreting degree at the University of Córdoba. A total of 47 participants out of 56 students enrolled in the course voluntarily agreed to undertake this activity that would have an impact on their final mark obtained through continuous assessment. These undergraduates were studying the third year of the Degree in Translation and Interpreting or one of the double degrees involving Translation and Interpreting (with English Studies or Hispanic Philology), and three Erasmus students joined the activity.

\subsection{Materials}

The materials used for the activity (throughout three stages) were available in a specific folder uploaded to the online learning platform Moodle, and the students' translations were submitted to the same folder. The materials provided were the following:

1. The short documentary film "Jellyfish 101" from National Geographic, lasting 3 minutes and 41 seconds. 
Ogea Pozo, M. (2020). Subtitling documentaries: A earning tool for enhancing scientific translation skills. Current Trends in Translation Teaching and Learning E, 7, 445478.

Figure 1. Opening of the documentary film "Jellyfish"

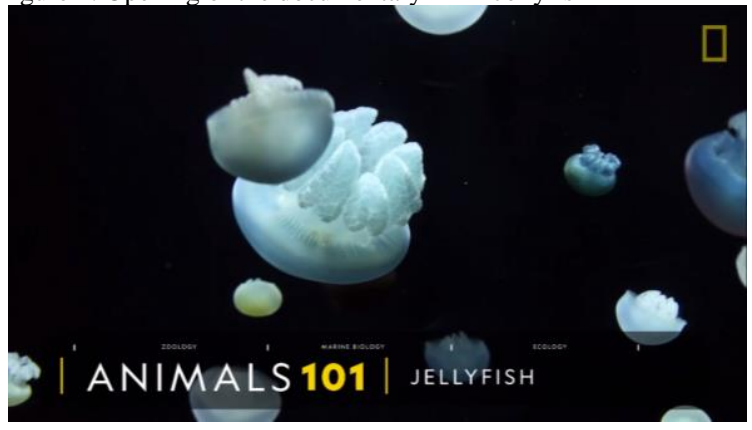

The documentary film consisted of a motion picture supported by an offscreen narration, as well as diagrams and on-screen text that could help viewers understand the discourse.

Figure 2. Example of an on-screen text

\section{MESOGLEA}

2. The transcription of the narration spoken during the documentary film. 
Ogea Pozo, M. (2020). Subtitling documentaries: A earning tool for enhancing scientific translation skills. Current Trends in Translation Teaching and Learning E, 7, 445478.

3. A questionnaire that would be answered by students once the activity is done. It was designed for this project, as a tool to measure the success and the outcome of the lesson, as well as to obtain their feedback about the potential use of subtitling as a learning tool.

4. Subtitling protocols. Although we intended to resemble a professional environment, deepening into style guides and subtitling protocols could be counterproductive for students, as they would not attend the course on Audiovisual Translation until the next academic year. Therefore, only a list of basic subtitling protocols was provided:

- Onscreen subtitles cannot exceed 38 characters per line and the maximum of lines is limited to two.

- Subtitles had been previously spotted, but students were informed about the "six-second rule", according to which a subtitle should not stay on screen less that one second or more than six seconds for two full subtitle lines (Díaz-Cintas and Remael, 2007, p. 96).

- Off screen voices must be represented in italics, if applicable. In this case, the narrator is the only speaker intervening in the documentary, so it is not necessary to particularize her speech with italics. 
Ogea Pozo, M. (2020). Subtitling documentaries: A earning tool for enhancing scientific translation skills. Current Trends in Translation Teaching and Learning E, 7, 445478.

- The translation must always be in synchrony with the image on screen.

- Spelling rules established by the Real Academia Española must be adhered to.

5. A free subtitle editor: Aegisub. Students can use this tool to watch the film, edit and manage subtitles, and proofread their final translation through full-screen display. They can work autonomously, facilitating the simulation of a real work assignment that may be challenging for them.

\subsection{Stages}

1. Viewing of the documentary film. This activity took place in the classroom and students identified specialized terminology, as well as differences between both linguistic systems. It is important to point out that we asked students to watch the film before carrying out the documentation phase, in order to assess to what extent visual information could work as a support for understanding the audiovisual text.

2. Translation of subtitles from English into Spanish and proofreading. The target text should be coherent with the information rendered by the rest of semiotic 
Ogea Pozo, M. (2020). Subtitling documentaries: A earning tool for enhancing scientific translation skills. Current Trends in Translation Teaching and Learning E, 7, 445478.

channels interacting in the audiovisual text. Students should pay attention to the register, the degree of formality and specialization, and standards specific to scientific texts.

3. Completion of the questionnaire. Students could assess the activity from different points of view: identification of unknown terminology, level of understanding, general evaluation (personal motivation, learning achievements, usefulness of semiotic codes).

\subsection{Outcomes}

With the aim of evaluating the activity, we must examine the responses gathered from the questionnaire. Firstly, students were asked to identify the topic and the main ideas addressed in the documentary (evolutionary history, behaviour, reproduction and immortality of jellyfish), and they acknowledged a significative level of understanding. Although students claim to not have fully understood the text, we observe that the majority $(72,3 \%)$ declared to have a high level of understanding, whereas a 14,9\% and a 12,8\% admitted having a medium and very high level of understanding, respectively. This data suggests that visual information has been an important 
Ogea Pozo, M. (2020). Subtitling documentaries: A earning tool for enhancing scientific translation skills. Current Trends in Translation Teaching and Learning E, 7, 445478.

reinforcement and we were able to confirm this hypothesis thanks to the responses when asked whether visual and auditive information allow them for understanding the text written in the English subtitles: 97,9\% answered affirmatively.

In the first section of the questionnaire, we asked questions related to the viewing and understanding of the audiovisual text. In the first place, we found that the interpretational listening improved their concentration and interpretation of the message, as $36,2 \%$ agreed and $27,7 \%$ strongly agreed that hypothesis, whereas $27,7 \%$ did not agree nor disagree and only $8,5 \%$ disagreed. Additionally, the great majority of them (a total of $87,3 \%$ ) reported that the presence of written subtitles on screen helped them to follow the story plot more accurately and easily. This confirms our hypothesis that subtitles enhance the benefits of audiovisual material. This positive reception of subtitling confirms that high motivation results in a better attitude towards the activity, a higher concentration and, therefore, a better learning experience.

On the basis of Díaz-Cintas' "comprehensible input" theory (2012, p. 98), we intended to verify if students rely on the information contained in the extralinguistic elements to overcome their lack of 
Ogea Pozo, M. (2020). Subtitling documentaries: A earning tool for enhancing scientific translation skills. Current Trends in Translation Teaching and Learning E, 7, 445478.

knowledge of the subject and whether, in turn, the fact that this information slightly exceeds their level of competence triggers their willingness to learn more. When asked whether they considered audiovisual material as a support to immerse more deeply in the main subject and a stimulation to undertake the translation task, a vast majority agreed or strongly agreed (34\% and 61,7\%, respectively), and just a $4,3 \%$ of the respondents did not agree nor disagree. Therefore, this leads us to believe that, in addition to the oral speech, visual information is a key input for the students' immersion in the subject and fosters a positive "affective filter" (Krashen, 2009 , p. 31) as a result of the appealing interaction of different sign systems. According to Krashen, the affective filter embodies variables such as motivation, self-confidence and anmatamalaxiety, and affects the part of the brain responsible for language acquisition, meaning that a positive attitude will result in a great deal of comprehensible input for the acquirer.

The second section of the questionnaire deals with the specific lexical units in the text. We needed to know if during the translation/subtitling process, they felt able to explore the interaction between language and science, by observing the linguistic constructions, collocations and terminology within 
Ogea Pozo, M. (2020). Subtitling documentaries: A earning tool for enhancing scientific translation skills. Current Trends in Translation Teaching and Learning E, 7, 445478.

a specialized context. The results were positive, as $48,9 \%$ agreed and $29,8 \%$ strongly agreed to have paid attention to these aspects during the subtitling process.

Subsequently, they compiled a list of terms that they considered to be specialized, and which they did not or only partially know. The full list of terms mentioned by some or all the participants is as follows:

Table 1. List of terms considered as specialised or specific to the topic

\begin{tabular}{|l|l|}
\hline \multicolumn{2}{|c|}{$\begin{array}{c}\text { SCIENTIFIC TERMS FOUND IN THE } \\
\text { AUDIOVISUAL TEXT }\end{array}$} \\
\hline Aging process & Mesoglea \\
\hline Backbones & Phyla \\
\hline Bell & Polyp \\
\hline Blooms & Sea jellies \\
\hline Box jellyfish & $\begin{array}{l}\text { Sensory } \\
\text { organs }\end{array}$ \\
\hline Cardiac arrest & Smacks \\
\hline Chironex & Stingers \\
\hline Fleckeri & Stings \\
\hline Clogging & Swarms \\
\hline Oesophagus & Tentacles \\
\hline Species & \\
\hline
\end{tabular}


Ogea Pozo, M. (2020). Subtitling documentaries: A earning tool for enhancing scientific translation skills. Current Trends in Translation Teaching and Learning E, 7, 445478.

\begin{tabular}{|l|l|}
\hline Hydrozoan & $\begin{array}{l}\text { Transdif- } \\
\text { ferentiation }\end{array}$ \\
\hline Invertebrates & $\begin{array}{l}\text { Turritopsis } \\
\text { Dohrnii }\end{array}$ \\
\hline $\begin{array}{l}\text { Mating } \\
\text { purposes }\end{array}$ & Umbrella \\
\hline
\end{tabular}

The table above is a demonstration of the strong presence of specialised terminology in an informational short documentary film, so this genre is proven to be an adequate audiovisual learning tool in the context of the course Scientific Translation. However, students reported to have been able to partially understand the meaning of the mentioned lexical units thanks to the additional information delivered by the image. Additionally, we focused on the effectiveness of the multisemiotic system linguistic, visual and audio - for a better acquisition of FL specialised vocabulary, and found out that $14,9 \%$ of respondents did not agree nor disagree, but a significant percentage of $48,9 \%$ and $36,2 \%$ agreed or strongly agreed with this theory, respectively. These responses proved that the learner's cognitive capacity increased due to the presence of verbal and visual information-processing channels (Mayer, 2009).

On the other hand, we explored the benefits of subtitling for the identification of different syntax 
Ogea Pozo, M. (2020). Subtitling documentaries: A earning tool for enhancing scientific translation skills. Current Trends in Translation Teaching and Learning E, 7, 445478.

and lexical semantic conceptual structures in both languages, as well as for the acquisition of specialized terminology. Once again, we obtained results that reinforced our hypothesis that subtitling may be an optimal learning tool involving scientific translation skills, as the great majority admitted to have learned about lexical and semantic standards for scientific texts in both languages, and to have experienced a better comprehension and acquisition of scientific terminology.

The last section of the questionnaire required a general assessment of the activity in terms of learning outcomes, motivation towards the activity and opinion about the documentary genre. The results were optimistic, as $25,5 \%$ and $74,5 \%$ of respondents agreed or strongly agreed, respectively, that this learning method successfully simulated a professional environment, and that fact turn out to be dynamic and challenging, raising their personal motivation towards the realization of the activity. In this sense, students also reported that the use of subtitles and the subsequent translation into Spanish boosted their ability to detect and memorize specialized terminology, and the most of them $(51,1 \%$ and $38,3 \%)$ agreed or strongly agree that they would consider documentaries as a form of 
Ogea Pozo, M. (2020). Subtitling documentaries: A earning tool for enhancing scientific translation skills. Current Trends in Translation Teaching and Learning E, 7, 445478.

audiovisual documentation for future assignments of translation of scientific texts.

We inquired whether the students felt that, in general terms, the viewing of the documentary and the subsequent subtitling practice had been effective for the acquisition of knowledge related to the translation of scientific texts within this area of expertise. We found that $100 \%$ of the respondents admitted having improved their skills after the completion of the exercise.

\section{DISCUSSION AND CONCLUSIONS}

Undoubtedly, andiovisual media is proven to be an excellent material in educational contexts, as the presence of information in multiple channels stimulates learners' motivation and cognitive capacity. Among the different teaching methods based on the use of subtitles, the practice of interlinguistic subtitling is not frequently taken into account, as literature has been mainly focusing in FL learning in the broadest sense. However, this exercise is both appealing and challenging for Translation and Interpreting students and can provide a variety of benefits from different points of view. On the other hand, in the light of the literature revised in this paper we can confirm that the 
Ogea Pozo, M. (2020). Subtitling documentaries: A earning tool for enhancing scientific translation skills. Current Trends in Translation Teaching and Learning E, 7, 445478.

documentary genre may be an adequate learning tool applied to the development of scientific translation skills. Therefore, the simulation of proffesional projects consisting of subtitling scientific documentary films can be an interesting proposal in the context of a Scientific Translation course.

Once the outcomes of the questionnaires and exercises have been compiled, we feel encouraged by the notably active participation of the students enrolled in this course. Their responses manifest a very good valuation of the benefits provided by audiovisual material in terms of the development of skills related to textual comprehension, identification of lexical semantic and syntactic structures, standards of textuality, characteristics of scientific texts, and acquisition of specialised terminology. Therefore, there seems to be clear that the interaction of different semiotic systems brings forth a complete and effective FL learning in the context of specialised fields and, consequently, in the context of specialised translation. The positive student behaviour favours a productive working environment in which they can translate autonomously and can build referential connections between text and image which allow them to interpret and memorize information, and to learn in 
Ogea Pozo, M. (2020). Subtitling documentaries: A earning tool for enhancing scientific translation skills. Current Trends in Translation Teaching and Learning E, 7, 445478.

a more efficient way. As a conclusion, we can say that the project delivered auspicious learning outcomes, as most of the participants rated the subtitling activity 4 or 5 , with regard to the motivation aroused and their learning experience.

It is worth mentioning that the students underwent a final exam that required the translation of a scientific written text related to the same topic (entitled "Are Jellyfish Taking Over The World?" and extracted from the Journal of Aquaculture \& Marine Biology), but this information had not been previously announced to them. The results were as follows:

- $100 \%$ of the students who had done this exercise successfully passed the exam.

- The marks obtained by the 42 students who completed the project were relatively high: eight of them passed with a mark between 5-6 (up to 10), twenty-five obtained a mark oscillating between 7 and 8 , and nine of them obtained a mark between 9 and 10 .

In the light of the above data, we can assert that the simulation of a professional project - consisting of subtitling a scientific documentary film - allows for the acquisition of specialised vocabulary, the 
Ogea Pozo, M. (2020). Subtitling documentaries: A earning tool for enhancing scientific translation skills. Current Trends in Translation Teaching and Learning E, 7, 445478.

improvement of reading and listening skills, the strengthening of translation skills in the field of scientific translation, and the pragmatic contextualisation. We must not forget the students' profiles, as they are young people who are familiar with the multimedia environment and feel comfortable with handling audiovisual media, so this fact makes the activity appealing and amusing for them. This is evidenced by the figures that demonstrate their level of motivation and textual understanding. We believe to have corroborated that the presence of several semiotic systems achieves a greater and better understanding of the information rendered and, consequently, a cooperative attitude in the classroom. As a final consequence, this mindset enables students to gain a higher degree of knowledge on the subject and a fruitful learning of specialized terminology. Moreover, we can declare that the subtitling of the documentary genre functions as an excellent tool to be applied to train and enhance skills required for scientific translation. Based on the results attained in the final grades, we have verified that it has a positive influence among students enrolled in this course, which occasionally happens to be "less popular" due to the amount of specific difficulties posed during the learning process. This hybrid - audiovisual and scientifictext shifts the students' vision of scientific texts 
Ogea Pozo, M. (2020). Subtitling documentaries: A earning tool for enhancing scientific translation skills. Current Trends in Translation Teaching and Learning E, 7, 445478.

dealing with subjects they do not know, since the comprehensible input present in all the semiotic codes is both stimulating and attractive, and the possibility of producing their own subtitles on screen and watching the subtitled documentary once the task is finished is very satisfactory and inspiring.

\section{REFERENCES}

Cabré, M.T. (1999). La terminología: Representación y comunicación. Universitat Pompeu Fabra University Press.

Díaz-Cintas, J. (2012). Los subtítulos y la subtitulación en la clase de lengua extranjera. Abehache, Revista da Associação Brasileira de Hispanistas, 2, 95-114.

Díaz-Cintas, J. and Remael, A. (2007). Audiovisual translation: subtitling. St. Jerome Publishing.

García Luque, F. (2010). Problemas de traducción de los documentales de temática científica. In E. Ortega, and M. MarÇalo (Eds.), Lingüística e Tradução na Sociedade do Conhecimiento (pp. 385-397). Editorial Atrio. 
Ogea Pozo, M. (2020). Subtitling documentaries: A earning tool for enhancing scientific translation skills. Current Trends in Translation Teaching and Learning E, 7, 445478.

Gottlieb, H. (2004). Language-political implications of subtitling. In P. Orero (Ed.), Topics in audiovisual translation (pp. 83-100). John Benjamins.

Incalcaterra McLoughlin, L. and Lertola, J. (2014). Audiovisual translation in second language acquisition. Integrating subtitling in the foreign-language curriculum. The Interpreter and Translation Trainer, 8:1, 7083.

King, J. (2002). Using DVD feature films in the EFL classroom. Computer assisted language learning, 15/5, 509-523.

Krashen, S.D. (2009). Principles and Practice in Second Language Acquisition. Internet Edition. University of Southern California.

León, B. (2001). Divulgación científica y documental televisivo. Estudio de las obras de David Attenborough. Treballs de la Societat Catalana de Biologia, Vol. 51, 253266. 
Ogea Pozo, M. (2020). Subtitling documentaries: A earning tool for enhancing scientific translation skills. Current Trends in Translation Teaching and Learning E, 7, 445478.

León, B. (2002). La divulgación científica a través del género documental. Una aproximación histórica y conceptual. Mediatika, 8, 69-84.

Matamala, A. (2009). Main challenges in the translation of documentaries. In J. DíazCintas, New trends in audiovisual translation (pp.109-122). Multilingual Matters.

Mayer, R. (2009). Multimedia Learning, 2nd Edition. Cambridge University Press.

Neves, J. (2004). Language awareness through training in subtitling. In P. Orero (Ed.) Topics in Audiovisual Translation (pp. 127140) John Benjamins.

Ogea Pozo, M. (2018). Subtitulado del género documental: de la traducción audiovisual a la traducción especializada. Sindéresis.

Paricio Rojo, J. (2002). Claves del diseño de programas científicos para televisión. Mediatika, 8, pp. 85-113.

Sokoli, S., Zabalbeascoa, P. \& Fountana, M. (2011). Subtitling activities for foreign language 
Ogea Pozo, M. (2020). Subtitling documentaries: A earning tool for enhancing scientific translation skills. Current Trends in Translation Teaching and Learning E, 7, 445478.

learning: what learners and teachers think. In L. Incalcaterra, M. Biscio and M. Ní Mhainnín (Coord.), Audiovisual translation: subtitles and subtitling: theory and practice (pp. 219-242). Peter Lang.

Soler Pardo, B. (2017). La traducción audiovisual en la enseñanza de una LE: la subtitulación como herramienta metodológica para la adquisición de léxico. Tejuelo, 26, 163-192.

Talaván Zanón, N. (2012). Justificación teóricopráctica del uso de los subtítulos en la enseñanza-aprendizaje de lenguas extranjeras. Trans, 16, 23-37. 